\title{
Microbial Effects on Geochemical Parameters in a Tropical River Basin
}

\author{
Sivanandham Vignesh • Hans-Uwe Dahms • \\ Periyasamy Kumarasamy • Annamalai Rajendran • \\ Bong-Rae Kim • Rathinam Arthur James
}

Received: 30 September 2014 / Accepted: 17 January 2015 / Published online: 17 February 2015

(C) Springer International Publishing Switzerland 2015

\begin{abstract}
Domestic sewage discharge and live stocks are the main sources of pathogenic contaminations in rivers. The river Tamiraparani in southern India is affected by such nonpoint source pollution throughout the year. We collected a total of 264 samples (water and sediment) from 22 locations in 2-month intervals during a period of 1 year. Bacteriological analysis such as total viable counts (TVC), total coliform (TC), total Streptococcus (TS), Vibrio like organisms (VLO) and five pathogens as well as 12 geochemical parameters ( $\mathrm{pH}, \mathrm{EC}, \mathrm{TDS}, \mathrm{Cl}, \mathrm{HCO}_{3}, \mathrm{Ca}, \mathrm{Mg}, \mathrm{Na}, \mathrm{K}, \mathrm{PO}_{4}$, other nutrients and total hardness) were studied. Principal Component Analysis (PCA) and correlation analysis proved that microbial communities were separated with geochemical parameters in order to gain their efficacy. Factor analysis confirmed separate loading rates of microbial (32.3\%) and geochemical (32.7\%) parameters representing 'allochthonous - geochemical' and 'fecal matters - microbial' interactions, respectively. We used geographical information systems (GIS) for mapping the occurrence of indicator organisms from non-point sources throughout the river basin.
\end{abstract}

Keywords Bacteriological analysis · Indicator organisms · Geographical information system · Tamiraparani river

S. Vignesh $\cdot$ P. Kumarasamy $\cdot$ A. Rajendran $・$ R. A. James $(\bowtie)$

Department of Marine Science, Bharathidasan University, Tiruchirappalli 620024 Tamil Nadu, India e-mail: james@bdu.ac.in

Rathinam Arthur James

e-mail: james.msbdu@gmail.com

H.-U. Dahms

Department of Biomedical Science and Environmental Biology, KMU - Kaohsiung Medical University, No. 100, Shin-Chuan 1st Road, Kaohsiung 80708, Taiwan

B.-R. Kim

Inland Aquaculture Research Center, National Fisheries Research and Development Institute, Jinhae-gu, Changwon-si, Kyungsangnam-do 114-3, South Korea 


\section{Introduction}

Availability of water is a critical factor for the socio-economic development in many countries and hence in most parts of the world freshwater supplies are put to heavy use (Korfali and Jurdi 2009). At present, the annual freshwater consumption is around $4000 \mathrm{~km}^{3}$ worldwide with the Indian consumption being $10 \%$ of this value (Madavan and Subramanian 2001). But the quantity of freshwater demands does not reflect the problems associated with water quality parameters such as toxic metal, pesticide, and bacterial contamination. River banks offer multiple uses in several sectors of development like agriculture, industry, transportation, aquaculture, and public water supplies (Kumarasamy et al. 2013). Rivers have also been used for cleaning and disposal of waste and may become polluted by indiscriminate disposal of sewage, industrial waste, agricultural practices and human activities, which all affect their microbiological quality (McLellan and Salmore 2003; Yillia et al. 2008a; Lorenzen et al. 2010; Vignesh et al. 2012; Al-Gheethi and Ismail 2014). For the assessment of river water quality, it is important to obtain not only the physicochemical characteristics but also information on whether the river conforms to prescribed standards of microbiological water quality (APHA 1998).

Billions of people worldwide suffer from diseases that are linked to water pollution, and most of the victims are children in developing countries (WHO 2012). Safe drinking water would prevent around 2.5 million deaths caused by diarrheal diseases, 150 million cases of schistosomiasis and 75 million cases of trachoma every year (Hinrichsen et al. 2000). Prevention of river pollution, therefore, also requires effective monitoring of microbiological parameters (Kumarasamy et al. 2009). Detection and enumeration of indicator organisms are of primary importance for the monitoring of sanitary and microbiological quality of water (Vignesh et al. 2013). Bacteriological parameters of different river systems have been studied by various researchers (Niewolak 1998; George et al. 2001; Sood et al. 2008; Vignesh et al. 2014). Aitken (2003) investigated the potential risk of fecal contamination due to diffuse pollution in river catchments and coastal bathing waters using indicator organisms. Yillia et al. (2008b) also suggested that diffuse pollution in the aquatic environment could be caused by people and livestock, leaving littered biofeces in the waters and along the river banks. They originate from the intestinal tract of warm-blooded mammals and humans, and are commonly released to the environment with biofeces. The pollution of river waters by fecal materials is due to the discharge of raw or treated urban waste waters (Rosso et al. 2013). The microbiological quality of sediments at the sediment-water interface in bathing water has received particular attention (Arakel 1995). Generally, fecal indicator concentrations are higher in sediments than in the overlaying water column (Yillia et al. 2008a). Watershed studies should address potential pollution risks from sediments, which can serve as a reservoir for coliform bacteria (Buckley et al. 1998). Similarly, Kim et al. (2005) reported that pollution indicator organisms are attached to the surfaces of runoff solids in the Geum River, Korea.

The Tamiraparani river, southern India, is the lifeline for the majority of the population in cities, towns, and villages in its catchment area. Rural/urban sewage effluents, agricultural wastes and warm-blooded animal feces also contribute substantially to fecal pollution of the river basin. Earlier, the river basin was studied with different aspects like geochemistry, heavy metals, morphometric evaluation and trace organic pollutants (Ramesh et al. 2002; Ravichandran 2003; Kumarasamy et al. 2012; Solai et al. 2013; Magesh and Chandrasekar 2012). Geographical Information System (GIS) provides a potential tool for an effective understanding and the interpretation of complicated hydrological processes in river water quality assessments (Wilson et al. 2000; Malik and Nadeem 2011). This technique has been 
used to identify the microbial hot spots within the river basin based on spatial and temporal differences. The particular objective of the present study is to explore whether: season (characterized by monsoon or times of mass tourism), area or specific fecal contamination sources are responsible for the ongoing freshwater contamination; to find out an interrelationship between hydrogeochemical and microbial parameters responsible for the pollution risk within the river basin.

\section{Materials and Methods}

\subsection{Study Area and Sampling}

The Tamiraparani river (Fig. 1) is one of the perennial river basins in southern India, extending between $8^{\circ} 30^{\prime}$ to $9^{\circ} 15^{\prime} \mathrm{N}$ latitude and $77^{\circ} 10^{\prime}$ to $78^{\circ} 10^{\prime} \mathrm{E}$ longitude. It has a drainage area of $5369 \mathrm{~km}^{2}$ and extends for a distance of $\sim 150 \mathrm{~km}$. Irrigation occurs on $40 \%$ of the drainage basin, which utilizes about $90 \%$ of the surface water available in the basin. The river has six major tributaries and their annual mean flows are upper Tamiraparani (368 million cubic metre $\left(\mathrm{Mm}^{3}\right)$ ), Servalar $\left(289 \mathrm{Mm}^{3}\right)$, Manimuthar $\left(243 \mathrm{Mm}^{3}\right)$, Chithar $\left(119 \mathrm{Mm}^{3}\right)$, Pachaiyar $\left(100 \mathrm{Mm}^{3}\right)$ and Gadana $\left(55 \mathrm{Mm}^{3}\right)$ (Ravichandran 2003). There are eight anicuts (diversion weirs) to control water supply through irrigation channels in the main river. The post-monsoon season has a brief winter (January - February) and the following summer (March-May) is characterized by warm humid conditions.

We surveyed the Tamiraparani river system intensively in order to select different sites for sample collection. We collected a total of 264 samples (water and sediment) from 22 locations

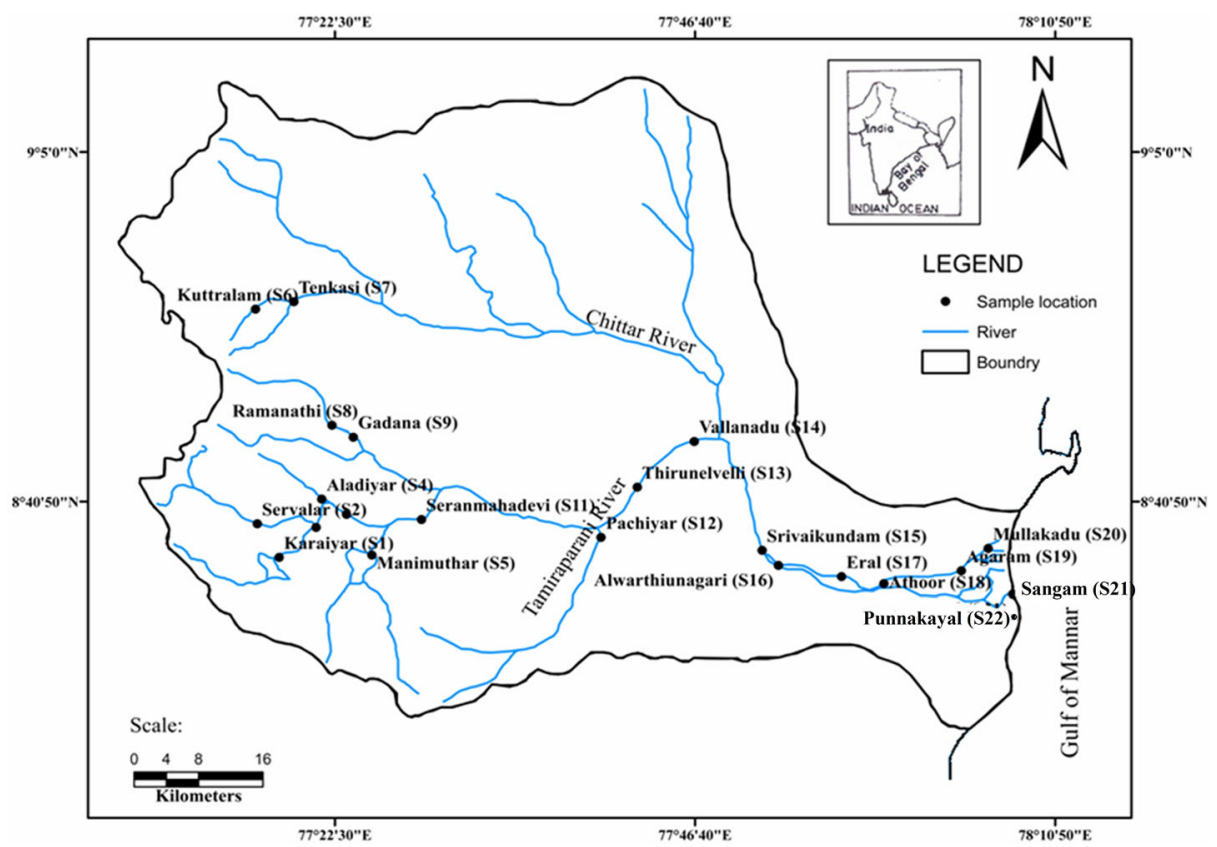

Fig. 1 Sampling locations in the study area 
within the river at 2-month intervals during a period of 1 year. Sampling locations were chosen to represent river locations receiving land drainages and other effluents. The river receives large quantities of land wastes, urban and rural sewage effluents, industrial and agricultural wastes throughout the year, especially in September to December, the months of intensive rainfalls (Kumarasamy et al. 2012). The river provides most of the water supplies to two major municipalities (Tirunelveli and Tuticorin) as well as to small towns and several villages of southern Tamil Nadu. Two liters of water samples were collected from 0 to $20 \mathrm{~cm}$ below the surface with a $2000 \mathrm{~mL}$ sterile container. The in situ parameters $\mathrm{pH}$, temperature $\left({ }^{\circ} \mathrm{C}\right)$ and electrical conductivity were measured immediately while sampling was done using a field kit (Thermo Orion 5-Star $\mathrm{pH}$ Multi-Meter). Furthermore, the samples were filtered through $0.45 \mu \mathrm{m}$ size fiber glass filters to remove suspended particles in the laboratory and then analyzed for major ion geochemical parameters using standard methods (APHA 1998). The sediment samples were collected (0-20 cm depth) at daytime by sterile spatula from inside the river bed. Approximately $250 \mathrm{~g}$ of sediment samples were collected and temporarily stored in aseptic polyethylene bags. All samples were collected with precautions required for microbiological analysis, kept on ice and immediately transported to the laboratory for further analysis. Sediment, $1 \mathrm{~g}$ wet weight (which varied always very slightly to dry weight) of the sample was mixed thoroughly by VORTAX (Spinix, India) with $10 \mathrm{~mL}$ of sterile double distilled water and allowed to settle, and the supernatant was used for inoculation.

\subsection{Bacteriological Analysis}

All the selective media were prepared with the addition of double distilled water and were properly autoclaved. Bacterial populations from two compartments (water and sediment) were studied by the spread plating method on selective medium plates with $0.1 \mathrm{~mL}$ of suitable serial dilutions (Nagvenkar and Ramaiah 2009). All the media plates were incubated at $37 \pm 1{ }^{\circ} \mathrm{C}$ for 24 to $48 \mathrm{~h}$ when final counts of colonies were noted. All trials were performed thrice - that means that three plates for the same sample and mean values were counted. Specific selective media were used for the enumeration of the bacterial types. Based on the manufacturer's guide of media and knowledge of previous analyses, the isolation and enumeration of bacteria were made using selective growth media such as nutrient agar for total viable counts (TVC), MacConkey agar for total coliforms (TC) and E. coli-like organisms (ECLO - EC), MEnterococcus agar for total Streptococci (TS) and Fecal Streptococci (FSLO - FS), Thiosulphate citrate bile salts sucrose (TCBS) agar for Vibrio like organisms (VLO) and Vibrio cholerae-like organisms (VCLO - VC), Xylose lysine deoxycholate (XLD) agar for Salmonella-like organisms (SALO - SA) and Shigella-like organisms (SHLO - SH), and Cetrimide agar for Pseudomonas aeruginosa-like organisms (PALO - PA) (Nagvenkar and Ramaiah 2009; Vignesh et al. 2012, 2013, 2014).

Recommended selective media were used for all organisms and they are, therefore, referred to as similar ("-like") to known microorganisms (LO). The typical colonies were grown in nutrient agar and incubated at $37 \pm 1{ }^{\circ} \mathrm{C}$ for $24-48 \mathrm{~h}$ followed by frequent subculture to fresh (nutrient broth) medium, and were used as pure cultures for identification. For identification of the organisms, typical colonies were inoculated into Rapid Microbial Limit Test kits recommended for diagnostic microbiology supplied by Hi-media Laboratories Limited (Table 1). The data were analyzed statistically by using analysis of variance (two factor ANOVA - to distinguish the effect of season and location on bacterial abundance), ORIGIN 8.0 and spatial distributions were illustrated by Arc-GIS 9.2 software. All the culture media were obtained from Hi-Media Pvt. Ltd., Bombay, India. 
Table 1 Details of culture media used for quantitative bacterial analysis

\begin{tabular}{|c|c|c|c|}
\hline S. No & Bacterial type & Culture medium & Positive Colonies \\
\hline 1. & Total Viable Count (TVC) & Nutrient Agar & All colonies counted \\
\hline 2. & Total Coliforms (TC) & MacConkey Agar & All colonies counted \\
\hline 3. & Total Streptococci $(\mathbf{T S})$ & M Enterococcus Agar & All colonies counted \\
\hline 4. & Vibrio Like Organisms (VLO) & TCBS Agar & All colonies counted \\
\hline 5. & Escherichia coli $(\mathbf{E C})$ & MacConkey Agar & Pink colonies counted \\
\hline 6. & Vibrio cholerae $(\mathbf{V C})$ & TCBS Agar & Yellow colonies counted \\
\hline 7. & $\begin{array}{l}\text { Salmonella sp. / Shigella sp. } \\
(\text { (SA / SH) }\end{array}$ & XLD Agar & $\begin{array}{l}\text { Pink dark black centered / } \\
\text { Pink colonies counted }\end{array}$ \\
\hline 8. & Streptococcus faecalis (SF) & M Enterococcus Agar & Pink colonies counted \\
\hline 9. & Pseudomonas aeroginosa (PA) & Cetrimide Agar & Green colonies counted \\
\hline
\end{tabular}

\section{Results}

We present here the average abundances of different bacterial populations in different seasons from water and sediment (Fig. 2). While differences in their abundances between the sampling locations were statistically significant (Table 2), there were strong signals of monthly
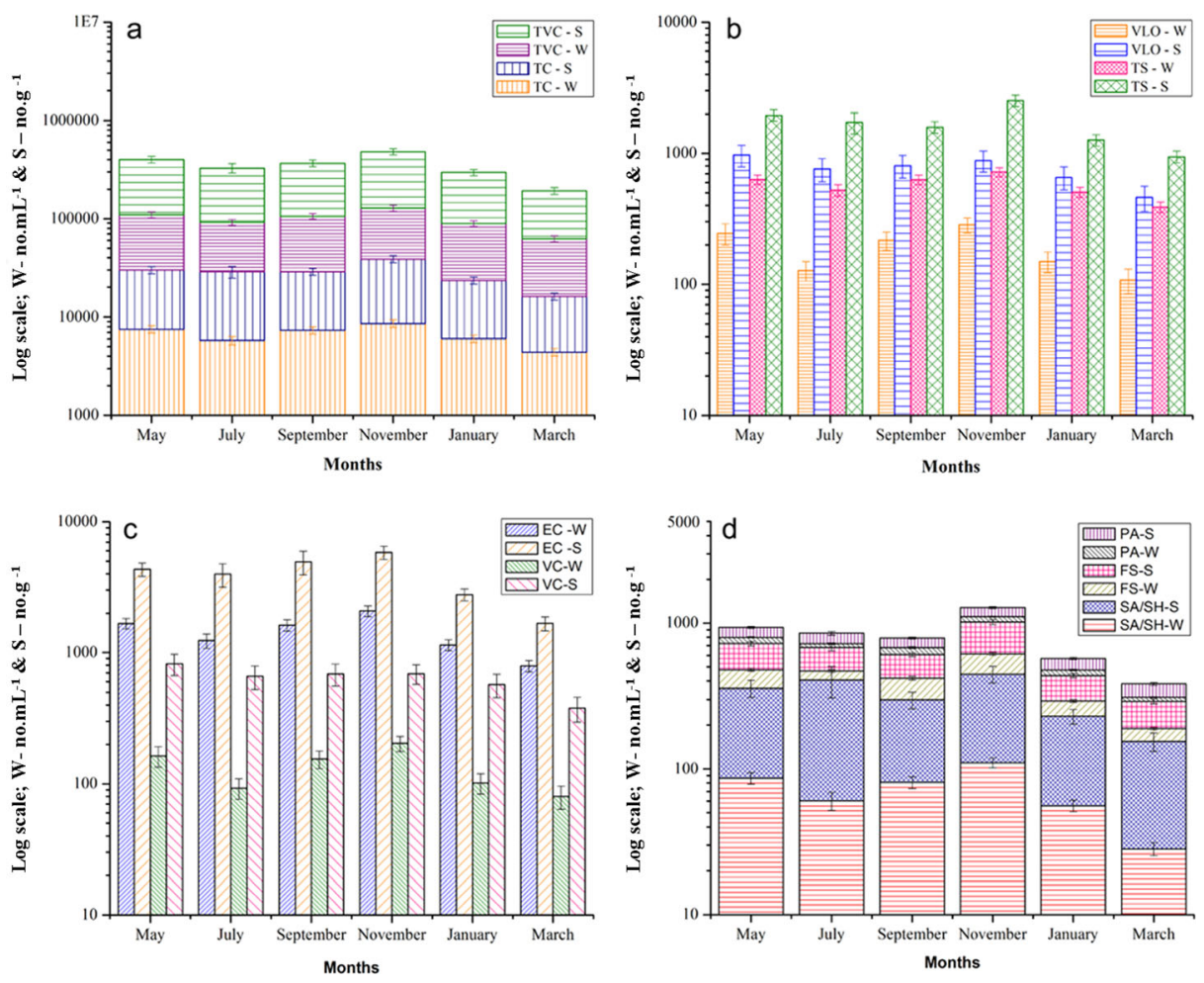

Fig. 2 Seasonal variations of indicators in water (W) and sediment (S) samples 


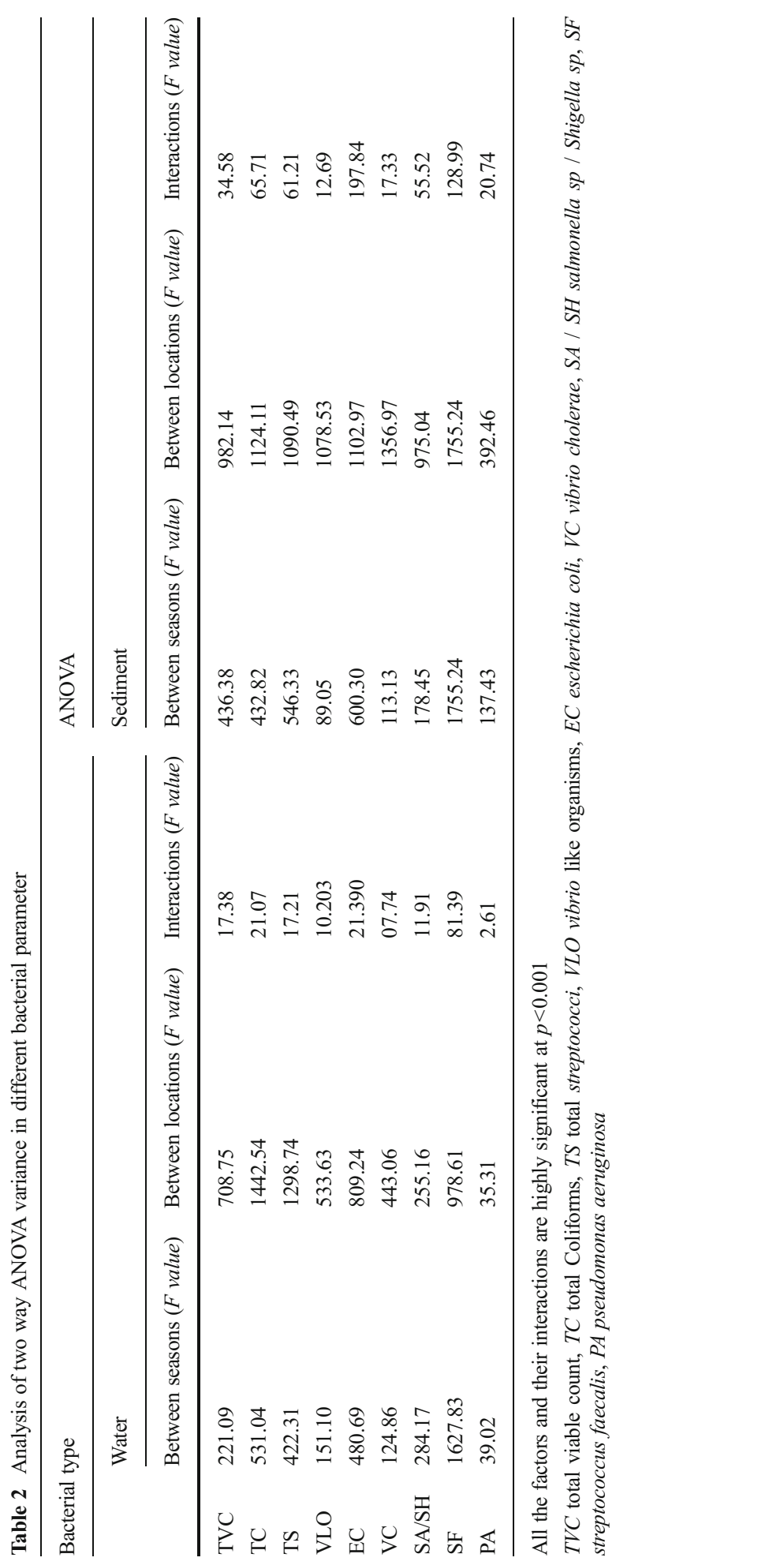


variations. The total viable counts (TVC) were an order of magnitude above $10^{3} \mathrm{~mL}^{-1}$ for all sites at all seasonal samplings in both water and sediment samples (Fig. 3). The TVC was relatively higher in November than in other months in all stretches of the Tamiraparani. Exceptionally, high TVC were found at the sites S6 and S7 of the upper stretch in July. However, the TVC of the middle and lower stretch were higher during the rainy season only compared to other seasons. The counts increased gradually from the upper to the lower stretches, i.e., sites of the middle and lower stretch were found to be more contaminated. In the water column, the mean TVC ranged from 1.1 to $14.2\left[\times 10^{4}\right] \mathrm{mL}^{-1}$ in November and from 3.5 to $85.0\left[\times 10^{3}\right] \mathrm{mL}^{-1}$ in March. Similar results were also obtained from sediment samples. In sediments, the mean TVC ranged from 2.4 to $94.0\left[\times 10^{4}\right] \mathrm{mL}^{-1}$ in November, and from 0.83 to $61.0\left[\times 10^{4}\right] \mathrm{mL}^{-1}$ in March. Variations in total viable counts (TVC) were large according to both months and river stretches. As for the water, the overall TVC were higher in November $\left(9.7-14.2\left[\times 10^{4}\right] \mathrm{mL}^{-1}\right)$ in the lower stretch than in the middle $\left(2.3-12.7\left[\times 10^{4}\right] \mathrm{mL}^{-1}\right)$ and upper stretch $\left(1.1-13.9\left[\times 10^{4}\right] \mathrm{mL}^{-1}\right)$.

Commonly, total coliform counts were relatively higher in November than in the other months, except at Kuttralam (S6) and Thenkasi (S7). A lower count of total coliforms was obtained in March and July. In the lower stretch, high values of TC were obtained in Eral (S17), Athoor (S18) and Punnakayal (S22). The stations S17, S18 were located in densely populated areas and S22 is a fishing harbor. In the middle stretch, higher counts were obtained in the areas of Tirunelveli (S13), Srivaikundam (S15), and Alwarthirunagar (S16), probably due to dense populations near the sampling sites. But in the upper stretch, high values were
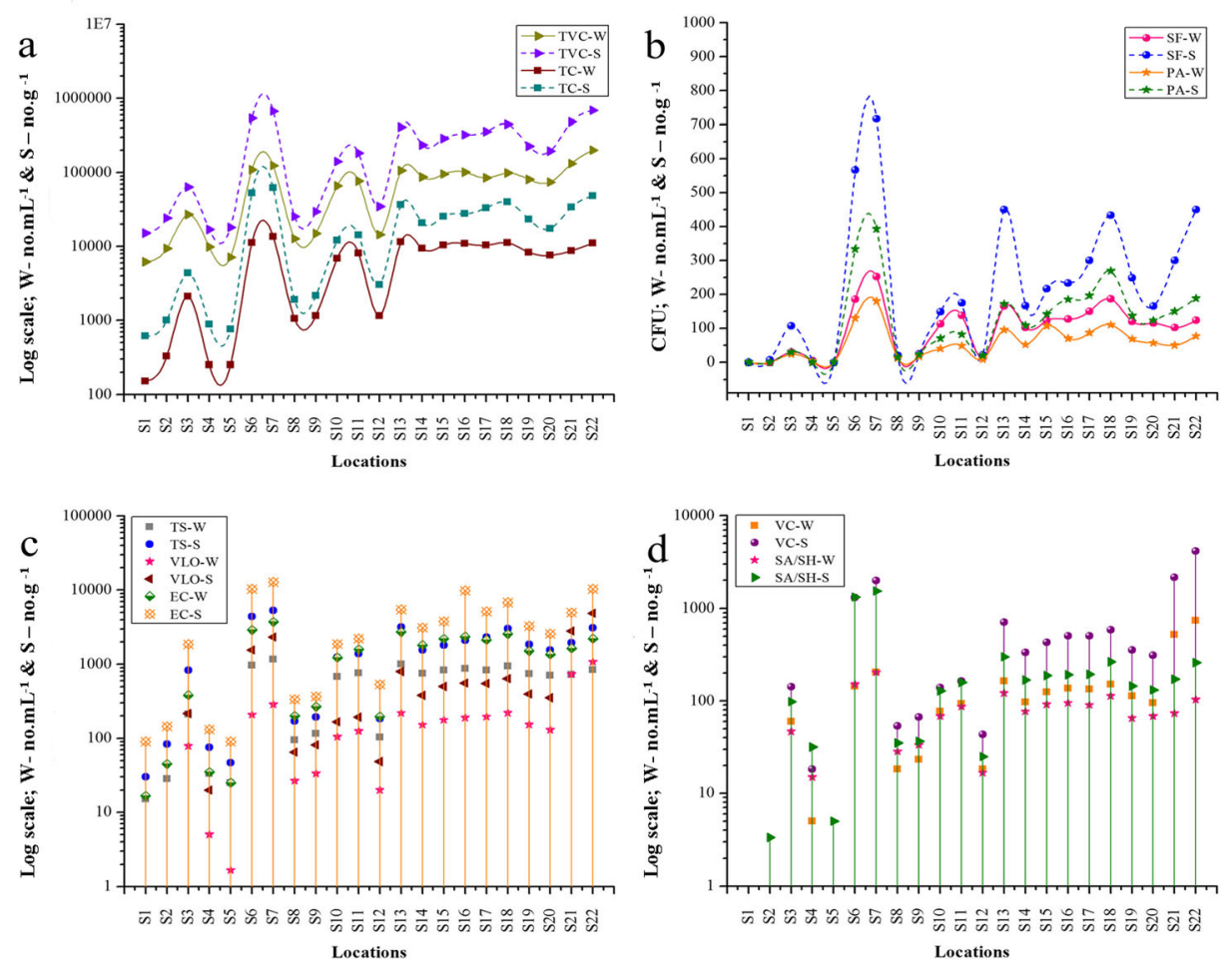

Fig. 3 Spatial distribution of Escherichia coli (EC) and Vibrio cholerae (VC) 
found in July in Kuttralam (S6) and Thenkasi (S7) which are prominent tourist places during the southwest monsoon. The values of TS were also higher during the rainy season, which is similar to the findings of TC. On the other hand, counts of TS in the upper region were low during most months. In the middle and lower stretches, higher values were obtained, especially at S13, S15, S16, S17, S18 and S22. Interestingly, TS counts were zero at some sites of the upper region (Karaiyar (S1), Servalar (S2) and Manimuthar (S5)) in March, July and January.

Vibrio like organisms (VLO) in the lower stretch were higher in most months, especially at Sangam (S21) and Punnakayal (S22), and elevated values were observed with $1000 \mathrm{~mL}^{-1}$ and $1600 \mathrm{~mL}^{-1}$ in May (Fig. 2). Similar to TS, the VLO was zero at some sites of the upper stretch such as at S1, S2, S3, S4, S5, S8 and S9 in March, July and January. In the middle stretch, Tirunelveli (S13), Srivaikundam (S15), and Alwarthirunagar (S16) provided increasing surveillance of VLO. However, in the upper stretch TC, TS and VLO counts were highest in November as compared to other months. But, S6 and S7 are major sites in the upper region, contributing very high loads of TC, TS and VLO in July followed by November, May, September, January and March. In July, other sites of the upper region did not show high bacterial amounts. In water samples, among the indicator bacterial groups such as TC and TS, counts were highest $0.3-16.6\left[\times 10^{3}\right] \mathrm{mL}^{-1}$ and $0.4-14.0\left[\times 10^{2}\right] \mathrm{mL}^{-1}$, respectively, in November, and least $0.5-88.0\left[\times 10^{2}\right] \mathrm{mL}^{-1}$ and $0-7.6\left[\times 10^{2}\right] \mathrm{mL}^{-1}$, respectively, in March. But VLO counts were highest $0-16.0\left[\times 10^{2}\right] \mathrm{mL}^{-1}$ in May and least $0-7.8\left[\times 10^{2}\right] \mathrm{mL}^{-1}$ in March. Among the sediment samples, the pathogenic indicator TC, TS and VLO ranges were $1.1-86.0\left[\times 10^{3}\right] \mathrm{g}^{-1}, 0.6-71.0\left[\times 10^{2}\right] \mathrm{g}^{-1}$ and $0-56.0\left[\times 10^{2}\right] \mathrm{g}^{-1}$ in November, respectively.

Similar results were shown by EC, SA/SH and SF. Briefly, in May and November, counts of human pathogenic $E$. coli were generally high at several locations; their counts were lower in March. The mean abundances of Salmonella sp. and Shigella sp. were moderate in September and January. Vibrio cholerae was present at high levels in the estuary area of the lower stretch such as at Sangam (S21) and Punnakayal (S22) throughout the period of investigation. Counts of SF varied widely between seasons. Similar to most other pathogenic groups, the PA counts showed lower levels at most sites in all seasons. In water samples, counts of EC, SA/ SH, SF and PA were in the range of $40-4900 \mathrm{~mL}^{-1}, 0-240 \mathrm{~mL}^{-1}, 0$ $410 \mathrm{~mL}^{-1}$ and $0-260 \mathrm{~mL}^{-1}$ in November, respectively. However, high $\mathrm{VC}$ counts were observed in May $\left(0-1000 \mathrm{~mL}^{-1}\right)$. In sediments, there were large variations in the abundance of different pathogenic bacterial types. In November, counts of EC, SA, SF and PA were in the range of $200-19,000 \mathrm{~g}^{-1}, 0-1800 \mathrm{~g}^{-1}, 0-1100 \mathrm{~g}^{-1}$, and $0-500 \mathrm{~g}^{-1}$, respectively, whereas VC showed high levels in May $\left(0-5300 \mathrm{~g}^{-1}\right)$.

Figure 4 shows the major ion chemistry and water quality status of the study area. It shows a pronounced variation over spatial and seasonal changes, and infers a good quality of the environment throughout the river basin (Kumarasamy et al. 2014). The spatial and temporal variations in different bacterial groups (EC, VC and SA/SH, SF) were covered in Figs. 5 and 6, respectively.

\subsection{Correlation and Principal Component Analysis (PCA)}

The correlation coefficient matrix (Table 3) shows a high positive relation with the following pairs: TVC-TC, TS, VLO, VC, EsC, SA/SH, SF and PA; TC-TS, EsC, SA/SH, SF and PA; TS-EsC, SA/SH, SF and PA; VLO-VC; EsC-SA/SH, SF and PA; SA/SH-SF and PA; SF-PA. The remaining pairs are moderatively correlated with each other. Positively correlated bacterial groups indicate their common origin. At the same time, a high positive correlation was found between $\mathrm{Cl}-\mathrm{VLO}$ and VC; Na- VLO and VC; $\mathrm{Na}-\mathrm{Cl}$ which proved that VLO could easily survive in salt tolerant places (Nagvenkar and Ramaiah 2009; Vignesh et al. 2012). A positive 

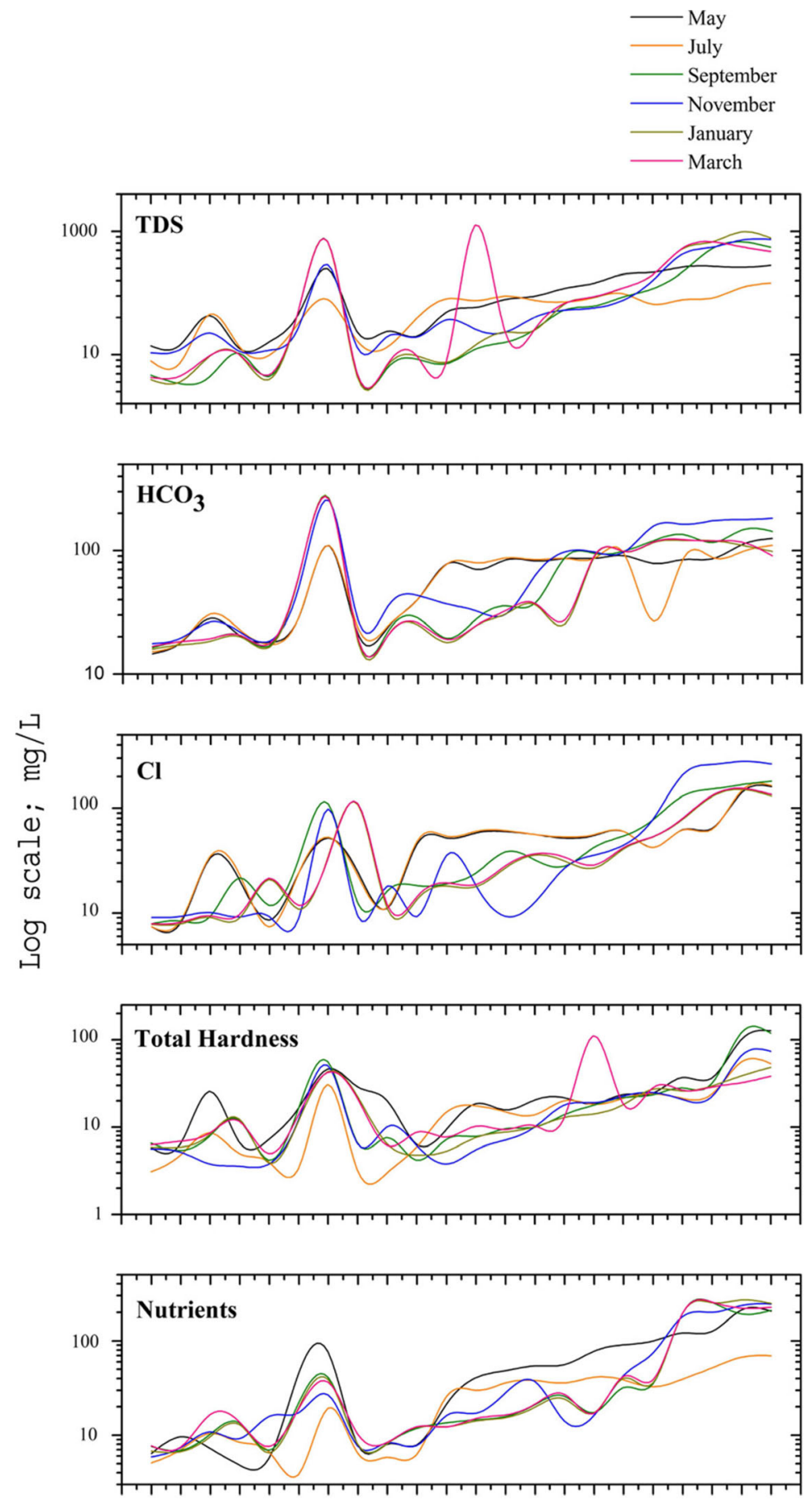

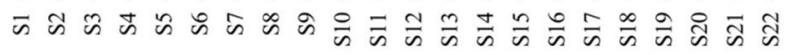

\section{Locations}

Fig. 4 Spatial variations of geochemical parameters (after Kumarasamy et al. 2013) 


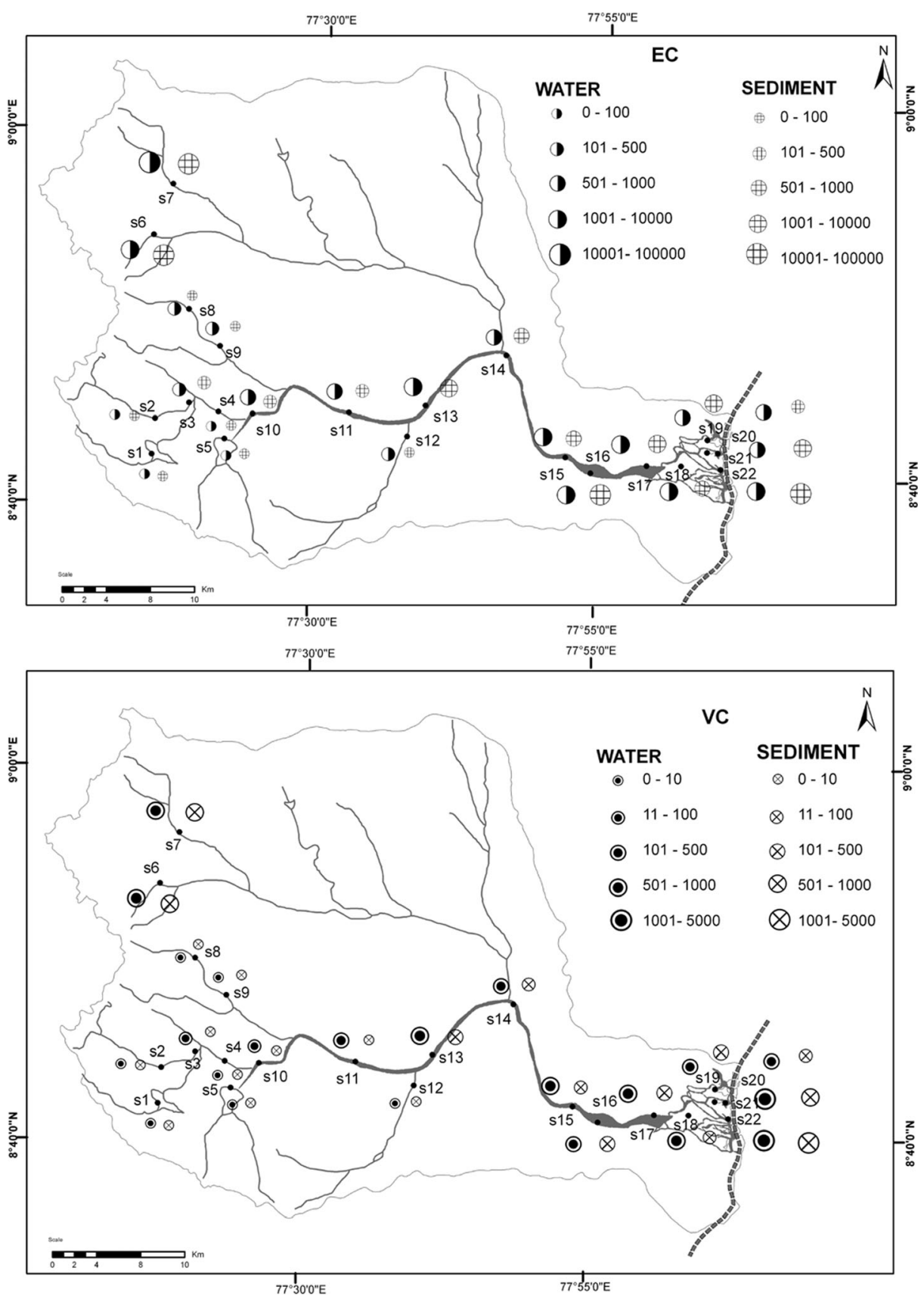

Fig. 5 Spatial variations of indicators in water (W) and sediment (S) samples

correlation between the bicarbonate and the bacterial parameters is explained by alkaline $\mathrm{pH}$ and not solely to bicarbonate alone. Commonly, bicarbonate is bacteriostatic rather than bactericidal, but it can induce alkaline $\mathrm{pH}$ or higher osmolality. Interestingly, in this study, 


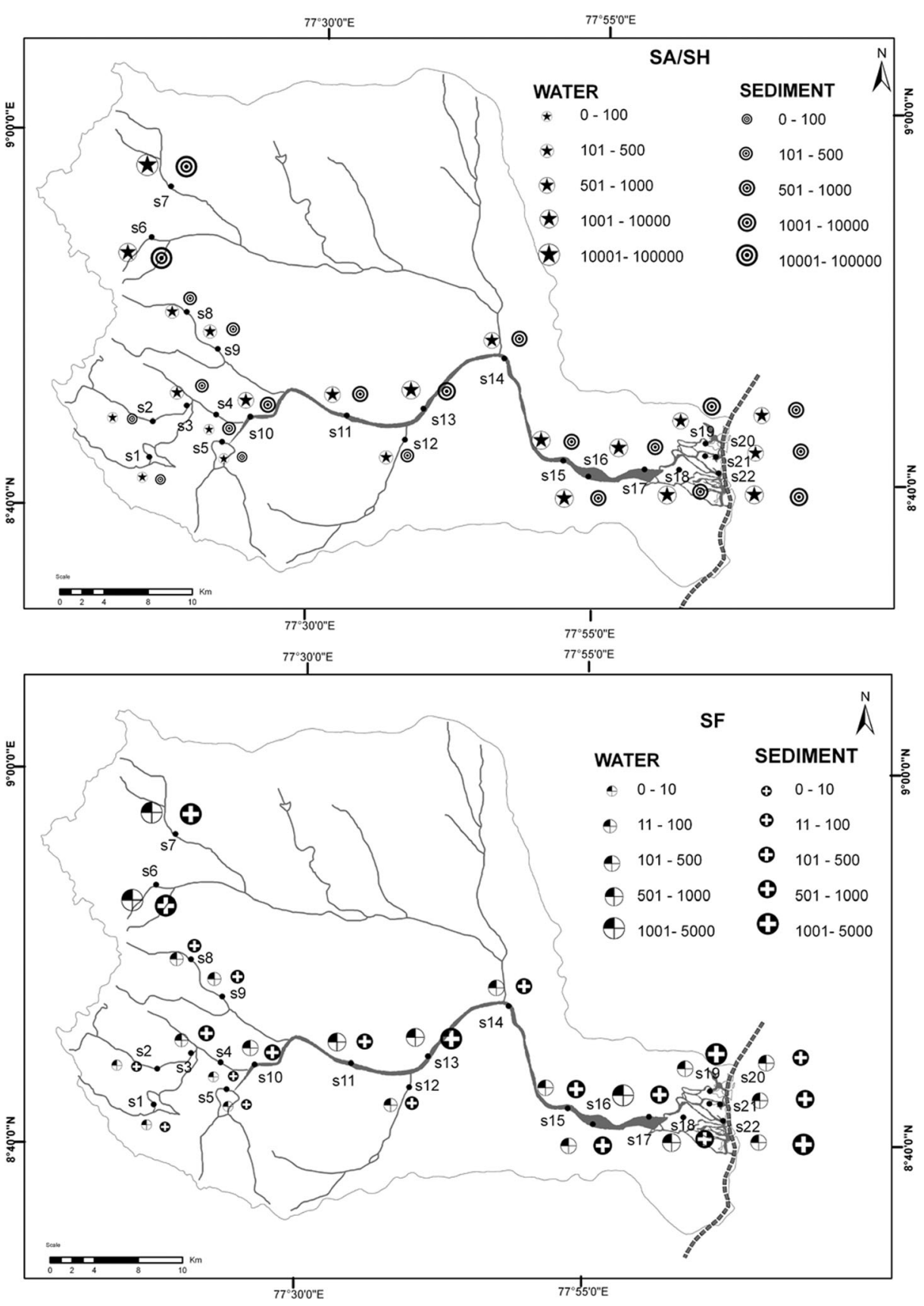

Fig. 6 Spatial distribution of Salmonella sp./Shigella sp. (SA/SH) and Fecal Streptococci (FS)

ions including bicarbonate were supported to maintain a $\mathrm{pH}$ level of around 7 and were negatively influencing microbial growth. A scatter matrix plot (Fig. 7) was generated by Origin 8.0 software for the bacterial and geochemical data of the Tamiraparani river water. A 


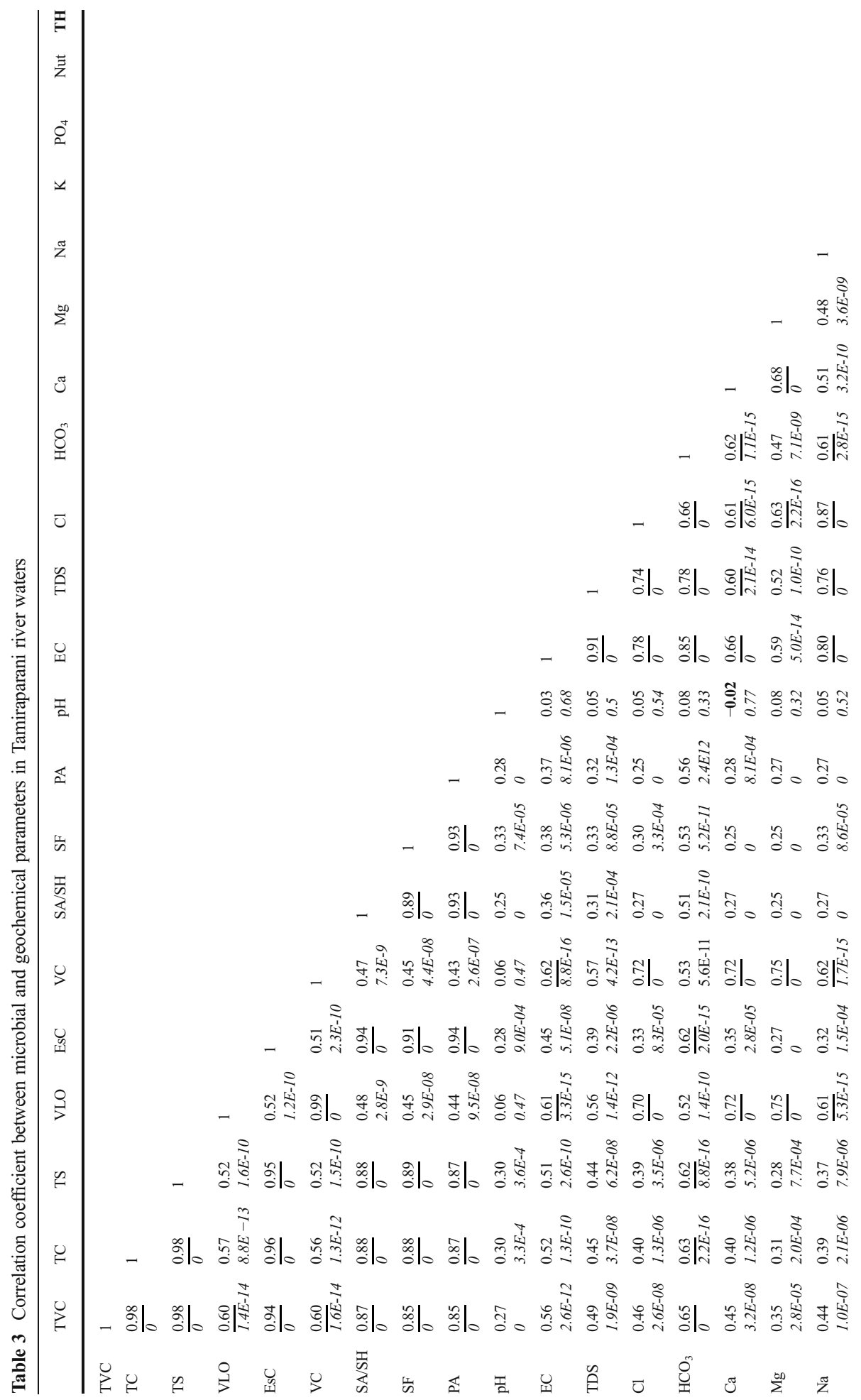




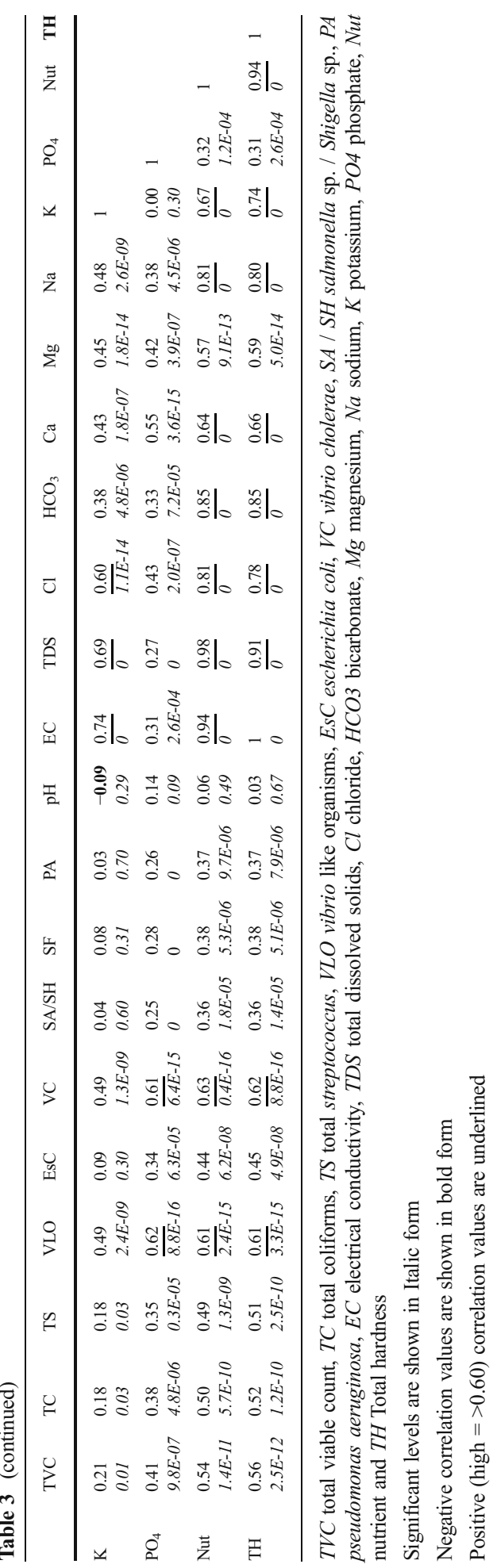




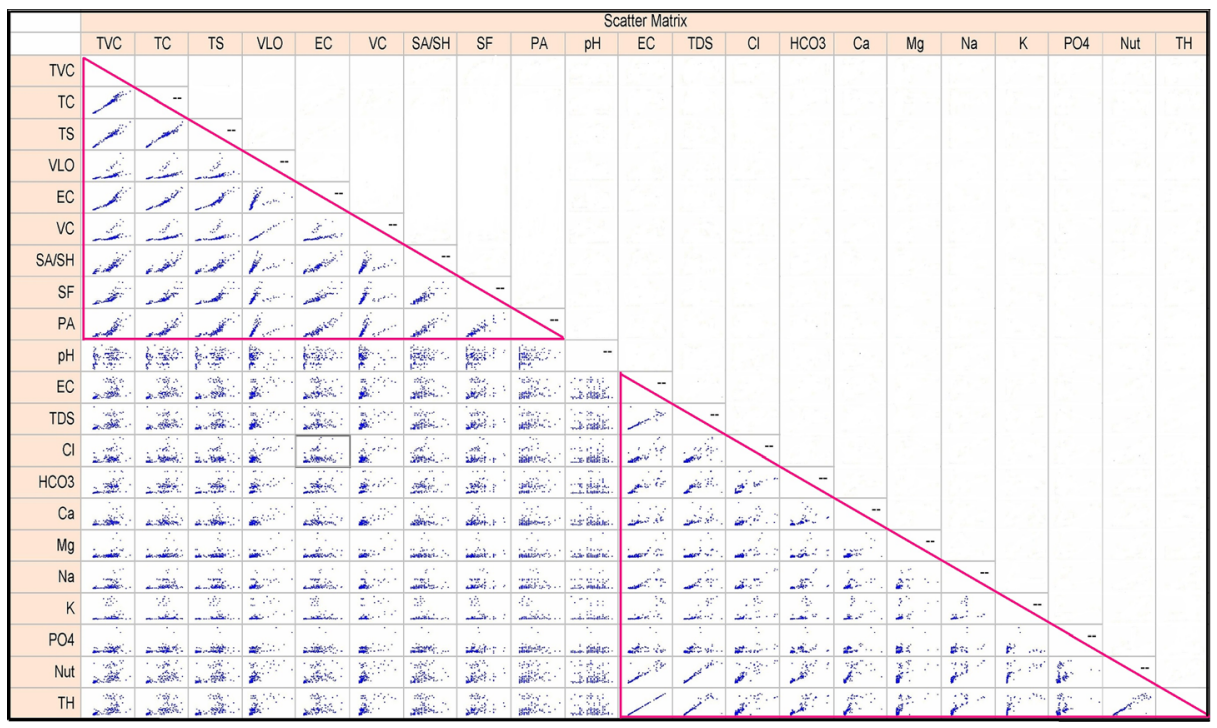

Fig. 7 Scatter matrix plot on inter relationship with microbial and geochemical parameters

static scatter matrix was used to obtain estimates of the co-variance matrix for instance of the normal distribution of multi-variance. A $45^{\circ}$ line diagonal plot indicates a strong relation of two variables while the distribution of the plot explains a lower relation between the variables. The pair-wise plots are simple and powerful to explain the univariate distribution of the variables. This plot also proves that microbial and physiochemical parameters were not mutually associated with each other in order to gain their efficacy.

To quantitatively evaluate the possible association between physicochemical and bacterial parameters (Eregno et al. 2014), we performed a simple statistical analysis, namely principal components analysis (PCA) with varimax normalization (PCA-V) and the results are given in Table 4. Overwhelming $32.74 \%$ of the total variance is contributed by factor I, showing higher loading for physico-chemical parameters such as EC (0.92), TDS (0.91), $\mathrm{Cl}(0.75), \mathrm{HCO}_{3}$ (0.74), $\mathrm{Na}(0.79), \mathrm{K}(0.79)$, Nut (0.92) and $\mathrm{TH}(0.93)$ (except $\mathrm{Ca}, \mathrm{Mg}$ and $\mathrm{PO}_{4}$ ), indicating the same geochemical origin of allochthonous river processes. Factor II, which had an equal loading rate of microbial parameters such as TVC (0.88), TC (0.91), TS (0.92), EsC (0.95), $\mathrm{SA} / \mathrm{SH}$ (0.93), SF (0.92) and PA (0.93), could be considered as 'fecal matter - microbial interaction' factors. It disclosed the contribution of human fecal matter, animal droppings, and sewage sources to the microbial pollution in river and estuarine waters (Vignesh et al. 2013). Factor III (17.54 \% of total variance), accounts with a high contribution of VLO (0.81), VC (0.80), $\mathrm{Ca}(0.67), \mathrm{Mg}(0.70)$ and $\mathrm{PO}_{4}(0.79)$, reflecting the control of different sources, like anthropogenic discharge associated with simple hardness (Nagvenkar and Ramaiah 2009).

\section{Discussion}

In the present study, most of the sites were found to have high TVC in both water and sediment. Most of the samples were found to have TVC higher than suggested by the Bureau of Indian Standard limits (BIS 1991). The water of the Tamiraparani river is used for drinking and domestic purposes in most places but high total viable pathogen levels suggest not to use 
Table 4 Principle component analysis (PCA) for microbial and geochemical parameters

\begin{tabular}{lllllll}
\hline Variables & Mean & SD* & Communalities & Factor I & Factor II & Factor III \\
\hline Eigen values & - & - & - & 6.875 & 6.784 & 3.684 \\
\% of variance & - & - & - & 32.736 & 32.303 & 17.545 \\
Cumulative \% & - & - & - & 32.736 & 65.040 & 82.585 \\
TVC & 64590.12 & 4412.42 & 0.939 & 0.315 & $\mathbf{0 . 8 7 8}$ & 0.262 \\
TC & 6577.34 & 4979.70 & 0.954 & 0.275 & $\mathbf{0 . 9 1 1}$ & 0.222 \\
TS & 560.45 & 410.49 & 0.944 & 0.278 & $\mathbf{0 . 9 1 5}$ & 0.171 \\
VLO & 184.69 & 265.97 & 0.913 & 0.400 & 0.306 & $\mathbf{0 . 8 1 2}$ \\
ESC & 1404.69 & 1240.15 & 0.976 & 0.204 & $\mathbf{0 . 9 5 0}$ & 0.176 \\
VC & 130.98 & 185.01 & 0.908 & 0.418 & 0.298 & $\mathbf{0 . 8 0 3}$ \\
SA/SH & 68.71 & 60.47 & 0.901 & 0.130 & $\mathbf{0 . 9 2 9}$ & 0.148 \\
SF & 91.36 & 92.23 & 0.898 & 0.163 & $\mathbf{0 . 9 2 5}$ & 0.126 \\
PA & 51.66 & 56.43 & 0.910 & 0.144 & $\mathbf{0 . 9 3 5}$ & 0.120 \\
pH & 7.42 & 0.56 & 0.157 & -0.083 & 0.386 & 0.035 \\
EC & 460.80 & 379.74 & 0.966 & $\mathbf{0 . 9 2 5}$ & 0.235 & 0.234 \\
TDS & 293.59 & 245.99 & 0.903 & $\mathbf{0 . 9 1 4}$ & 0.190 & 0.177 \\
Cl & 52.07 & 55.80 & 0.795 & $\mathbf{0 . 7 4 7}$ & 0.114 & 0.474 \\
HCO3 & 67.09 & 54.99 & 0.781 & $\mathbf{0 . 7 3 7}$ & 0.457 & 0.170 \\
Ca & 15.21 & 17.58 & 0.714 & 0.495 & 0.132 & $\mathbf{0 . 6 7 2}$ \\
Mg & 5.74 & 7.52 & 0.692 & 0.439 & 0.072 & $\mathbf{0 . 7 0 3}$ \\
Na & 25.35 & 37.03 & 0.737 & $\mathbf{0 . 7 8 6}$ & 0.134 & 0.320 \\
K & 18.32 & 40.52 & 0.674 & $\mathbf{0 . 7 9 3}$ & -0.112 & 0.179 \\
PO4 & 7.95 & 8.14 & 0.665 & 0.058 & 0.207 & $\mathbf{0 . 7 8 6}$ \\
Nut & 412.13 & 335.34 & 0.950 & $\mathbf{0 . 9 1 6}$ & 0.233 & 0.237 \\
TH & 468.23 & 379.73 & 0.966 & $\mathbf{0 . 9 2 5}$ & 0.236 & 0.234 \\
\hline
\end{tabular}

* SD standard deviation, PCA loadings $>0.60$ are shown in bold form, TVC total viable count, TC total coliforms, TS total Streptococcus, VLO Vibrio like organisms, EsC escherichia coli, VC vibrio cholerae, SA / SH salmonella sp. / Shigella sp., PA pseudomonas aeruginosa, EC electrical conductivity, TDS total dissolved solids, $C l$ chloride, $\mathrm{HCO}_{3}$ bicarbonate, $\mathrm{Mg}$ magnesium, $\mathrm{Na}$ sodium, $\mathrm{K}$ potassium, $\mathrm{PO}_{4}$ phosphate, $\mathrm{Nut}$ nutrient and $\mathrm{TH}$ total hardness

the water for such purposes at certain localities. The high TVC values may be attributable to the presence of large microbial populations residing in the sediment. In addition to pathogens, urine and feces contain organic matter as well as eutrophying macronutrients such as phosphorus and nitrogen compounds (Langergraber and Muellegger 2005). Heterotrophic bacteria commonly respond to pollution of this type by decomposing organic matter and releasing nutrients and energy (Obi et al. 2002; Jeevanandam et al. 2012). Frequent visits to surface water systems by the public and by livestock are common in developing countries. Particularly, poor rural communities lack access to potable clean water and they largely reside near river banks (Paruch et al. 2014). As a result, they often utilize surface waters for their daily washings and defecation which leads to contamination of the respective water bodies (Yillia et al. 2008b). These activities particularly deteriorate microbial water quality as fecal matter is disposed and the surrounding area is littered with feces (Reed et al. 2011; Chahinian et al. 2012).

In comparison to the Mondovi and Zuari river system (Nagvenkar and Ramaiah 2009), microbial pollution indicator counts were generally lower in the Tamiraparani river system. 
Escherichia coli and coliforms are commonly found in river waters as well as in effluent samples (Ramteke and Tewari 2002; Kumarasamy et al. 2009). Pollution indicator bacteria, such as TC, EC, TS, are examined for a better understanding of the preponderance of human pathogenic bacteria (APHA 1998). Higher sewage contamination would lead to an increased number of coliforms in surface water bodies. An understanding of as many individual groups as possible would be necessary for adequate river water monitoring considering different sewage outfall, animal input, mass bathing and other human activities (Nagvenkar and Ramaiah 2009; Wampler and Sisson 2011). Potent human pathogens such as Vibrio cholerae (causing cholera), Vibrio parahaemolyticus (causing gastroenteritis), Salmonella sp./ Shigella sp. (causing typhoid fever; food poisoning), Streptococcus sp. (causing meningitis and skin infections) and E. coli (causing diarrhoea) were abundant in most locations of the Tamiraparani river.

Kistemann et al. (2002) observed that during rainfall, the microbial loads of running waters may suddenly increase and reach reservoirs very quickly. These observations explain the increase in bacterial contamination from the upper to the lower stretches. The total coliform counts were relatively higher during the rainy month (November) than during other months, which suggest the enhancing role of precipitation on the density of microbial populations. The values for TS were higher during the rainy months with similar findings reported from the river Ganges (Sood et al. 2008). Highest TC and TS were obtained during the rainy period and were very low during the winter period. This can be explained by the relative frequency of TC from human sources that increase with rainfall (Baghel et al. 2005). In the present study, coliform bacterial populations were lowest in winter and highest during monsoon. A similar pattern was reported in earlier studies (Badge and Rangari 1999). During the rainy season, water runoff carries animal and human feces and sewage waste from the upper to the lower river stretches, leading to high counts of pathogenic indicators in the middle and lower stretch; there, dense population and substantial anthropogenic activity enhance microbial loads.

From the comparison of pollution indicators and pathogenic bacterial loads from the Tamiraparani river, it appears that the counts of all groups are lower than in the estuarine system of the Mandovi and Zuari river (Nagvenkar and Ramaiah 2009). Similarly, most of the pollution indicators and human pathogenic bacteria counts reported here were lower than those reported from the Seine river and its estuary in France (George et al. 2001), Mumbai waters in India (Ramaiah et al. 2004), and the Czarna Hancza river in Poland (Niewolak 1998). However, in the present study, most of the sites were not suitable for domestic use considering maximum permissible limits for TC and TS counts as per the standards laid down by the National River Conservation Directorate, India (NRCD). The Tamiraparani river water quality was greatly damaged by the influence of domestic and industrial wastes, and hence the pollution indicator ranges exceeded maximum acceptable levels $(5000 \mathrm{cfu} / 100 \mathrm{~mL})$. Fecal matter was degrading the water quality due to the possible introduction of pathogens, their toxins, nutrients and organic matter (Langergraber and Muellegger 2005; Moldovana et al. 2013). Pollution with fecal matter provides a significant health risk to the public (Byamukama et al. 2005) since fecal pellets contain several species of bacteria, including human pathogens (Hansen and Bech 1996). The level of risk depends considerably on the origin and level of contamination (Scott et al. 2002). In particular, contamination from human excreta and sewage discharge (Fujioka 2002) is of greater risk to public health as this is more likely to contain human-specific enteric pathogens.

Nagvenkar and Ramaiah (2009) reported Vibrio cholerae as the dominant bacterium in sewage discharges. It can rapidly outgrow the native microflora leading to increased levels of indicator bacteria in natural water bodies. Pathogenic bacteria of human health concern have been studied mostly with respect to their survival in riverine environments (Niewolak 1998; Kim et al. 2005; Sood et al. 2008; Moldovana et al. 2013). It becomes evident from the present 
study that the abundance of pathogenic bacteria fluctuates widely in water and sediment samples. This is because several water channels and tributaries confluence at different points of the study area. Nevertheless, environmental factors may affect the presence and die-off of microbes in aquatic systems (Wilkinson et al. 1995; Byamukama et al. 2005; Huang et al. 2011). Borst and Selvakumar (2003) found a significant amount of microorganism being associated with sediment particles during rainfall runoff and if pathogens discharged from watersheds were present in a form that could be adsorbed to a suspended particle then sedimentation processes should be implemented at contaminated sites to reduce public health risks. McLellan and Salmore (2003) have stated that resuspension of viable bacteria deposited in sediments may contribute to surface water loading with increased wave activity at the shoreline due to wind. Further, Wotton (2004) also reported that the incorporation of pathogens within surficial bed sediment (SBS) is actively facilitated by secretions of extracellular polymeric substances (EPS) during biofilm formation of the existing microbial populations.

Sediments may contain 100 to 1000 fold higher fecal coliform abundances than the overlying water column (Nagvenkar and Ramaiah 2009). The TVC in sediment was $<9.3 \pm$ $1.1 \times 10^{7} \mathrm{~g}^{-1}$ dry wt. in the Mandovi and Zuari river area (Nagvenkar and Ramaiah 2009). But during the present investigation the TVC population in the sediments was low (2.4-94.0 $\left[\times 10^{4}\right] \mathrm{g}^{-1}$ dry $\left.\mathrm{wt}\right)$ compared to above studies, owing to a smaller river basin $\left(5369 \mathrm{sq} . \mathrm{km}^{2}\right)$ and subsequently less intense natural and anthropogenic activities. As a result, bacteria levels increase by concomitant resuspension with sediments and/or resuspension of sediments with attached bacteria (Byamukama et al. 2005). Co-sedimentation, i.e., the joint deposition of sediment particles and bacteria is most likely the only way bacteria will settle in running waters (Wilkinson et al. 1995). The sediment/ bacteria association is further complicated by the potentially transient nature of the floc/bacteria relationship, due to the dynamic nature of flocculation processes. When viable bacteria attach to sediments, they are protected and their survival is enhanced (Droppo et al. 2009).

The Tamiraparani river is continuously polluted in the middle and lower stretch due to mass bathing (human and livestock), and indiscriminate sewage and septic tank waste discharges from the Tirunelveli municipality. However, the river demonstrated a considerable capacity and resilience to recover from pollution between these areas. It should be noted that the intrinsic capacity of water systems to recover from pollution is essential for restoring water quality to a pre-pollution status (Vagnetti et al. 2003). The geochemical levels show a pronounced variation over spatial and seasonal changes and infer a good quality of nature throughout the river basin (Kumarasamy et al. 2013). The poor/unsanitated dwellings and travelers/pilgrims depend largely on the river for their basic hygiene. The presence of such indicator organisms may provide an indication of waterborne problems and is a direct threat to human and animal health. Their abundance in the Tamiraparani river system suggests that they might provide suitable bio-indicators of enteric contamination. The river is mainly passing through several rural areas that have many small animal farms, and huge amounts of fecal excreta are dropped into the river system daily. Also, many pasture animals access this river system for their drinking purposes. In addition, large amounts of domestic sewage and small amounts of industrial effluents are discharged into the riverine system from urban/rural areas.

\section{Conclusions}

The present water/sediment quality bacteriological investigation suggests that the studied sites were heavily contaminated with TC, TS and pathogens. It is challenging at present to attribute fecal pollution to specific sources in the Tamiraparani river catchment area although people/ 
livestock could be the main contributing sources. Geochemically, although the river water characteristics range within permissible limits, most of the samples were found to have higher bacterial indicator levels than those demanded by the Bureau of Indian Standards and NRCD. In both water and sediment samples, the highest counts of bacteria were reported in November and May and moderate counts were made in other months. Higher bacterial densities were noted in the upper, middle and lower stretches at Thenkasi (S7), Tirunelveli (S13) and Punnakayal (S22), respectively, due to dense populations, mass visiting, and holy dipping. Among the five pathogenic bacterial examinations, Escherichia coli density exhibited the highest sensitivity to water quality changes. Based on this observation, the microbial contaminated communities were not associated with geochemical parameters. Guidelines to protect surface water quality of the Tamiraparani river are demanded.

Acknowledgments The authors would like to thank the University Grants Commission (UGC), Department of Science and Technology (DST) and NFRDI (Development of inland biofloc aquaculture technology 15-AQ-78) for financial assistance.

\section{References}

Aitken MN (2003) Impact of agricultural practices and river catchment characteristics on river and bathing water quality. Water Sci Tech 48:217-24

Al-Gheethi AAS, Ismail N (2014) Biodegradation of pharmaceutical wastes in treated sewage effluents by bacillus subtilis 1556WTNC. Environ Process 1(4):459-481. doi:10.1007/s40710-014-0034-6

APHA (American Public Health Association) (1998) Standard methods for the examination of water and wastewater, 19th edn. Washington, DC

Arakel AV (1995) Towards developing sediment quality assessment guidelines for aquatic systems: an Australian perspective. Aust J Earth Sci 42:335-369

Badge US, Rangari AK (1999) Periodicity of coliform bacteria in an aquatic environment. Water Sci Tech 40:151-157

Baghel VS, Gopal K, Diwedi S, Tripathi RD (2005) Bacterial indicators of faecal contamination of the Gangetic river system right at its source. Ecol Indic 5:49-56

BIS (Bureau of Indian Standards) (1991) Indian standard specification for drinking water. IS: 10500, Indian Standard Institute

Borst M, Selvakumar A (2003) Particle-associated microorganisms in storm water runoff. Water Res 37(1):215-223

Buckley R, Clough E, Warnken W, Wild C (1998) Coliform bacteria in streambed sediment in a subtropical rainforest conservation reserve. Water Res 32:1852-1856

Byamukama D, Mach RL, Kansiime F, Manafa M, Farnleitner AH (2005) Discrimination efficacy of faecal pollution detection in different aquatic habitats of a high-altitude tropical country, using presumptive coliforms, Escherichia coli, and Clostridium perfringens spores. Appl Environ Microbiol 71:65-71

Chahinian N, Bancon-Montigny C, Caro A, Gotb P, Perrin JL, Rosain D, Rodier C, Picot B, Tournoud MG (2012) The role of river sediments in contamination storage downstream of a wastewater treatment plant in low flow conditions: organotins, faecal indicator bacteria and nutrients. Estuar Coast Shelf Sci 114:70-81

Droppo IG, Liss SN, Williams D, Nelson T, Jaskot C, Trapp B (2009) Dynamic existence of waterborne pathogens within river sediment compartments. Implications for water quality regulatory affairs. Environ Sci 43:1737-1743

Eregno FE, Nilsen V, Seidu R, Heistad A (2014) Evaluating the trend and extreme values of faecal indicator organisms in a raw water source: a potential approach for watershed management and optimizing water treatment practice. Environ Process 1:287-309

Fujioka R (2002) Microbial indicators of marine recreational water quality. In: Hurst J, Crawford RL, Knudsen G, McIneney MJ, Stetzenbach LD (eds) C: manual of environmental microbiology, 2nd edn. American Society for Microbiology Press, Washington, pp 234-243

George I, Petit M, Theate C, Servais P (2001) Distribution of coliforms in the seine river and estuary (France) studied by rapid enzymatic methods and plate counts. Estuaries 24:94-102

Hansen B, Bech G (1996) Bacteria associated with a marine planktonic copepod in culture. I. Bacterial genera in seawater, body surface, intestines and fecal pellets and succession during fecal pellet degradation. J Plankton Res 18:257-273 
Hinrichsen D, Robey B, Cunkleman JA, Setty V (2000) Population and environment: The global challenge, Population Reports 28: No. 3 (serial online): http://www.jhuccp.org/pr/ popenviro

Huang S, Chen C, Wu Y, Wu Q, Zhang R (2011) Characterization of depth-related bacterial communities and their relationships with the environmental factors in the river sediments. World J Microbiol Biotechnol 27: 2655-2664

Jeevanandam M, Nagarajan R, Manikandan M, Senthilkumar M, Srinivasalu S, Prasanna MV (2012) Hydrogeochemistry and microbial contamination of groundwater from lower ponnaiyar basin, cuddalore district, Tamil Nadu, India. Environ Earth Sci 67:867-887

Kim TG, Choi E, Lee D (2005) Diffuse and point pollution impacts on pathogen indicator organism level in the Geum River, Korea. Sci Total Environ 350:94-105

Kistemann T, Claben T, Koch C, Dangendorf F, Fischeder R, Gebel J, Vacata V, Exner M (2002) Microbial load of drinking water reservoir tributaries during extreme rainfall and runoff. Appl Environ Microbiol 68:2188-2197

Korfali SI, Jurdi M (2009) Provision of safe domestic water for the promotion and protection of public health: a case study of the city of Beirut, Lebanon. Environ Geochem Hlth 31:283-295

Kumarasamy P, Govindaraj S, Vignesh S, Babu Rajendran R, Arthur James R (2012) Anthropogenic nexus on organochlorine pesticide pollution: a case study with Tamiraparani river basin, South India. Environ Monit Assess 184:3861-3873

Kumarasamy P, Dahms HU, Jeon HJ, Rajendran A, James RA (2013) Irrigation water quality assessment - an example from the Tamiraparani river. South India Arab J Geosci doi. doi:10.1007/s12517-013-1146-4

Kumarasamy P, James RA, Dahms HU, Buyon CW, Ramesh R (2014) Multivariate water quality assessment from the Tamiraparani river basin. South India Environ Earth Sci 71:2441-2451

Kumarasamy P, Vignesh S, Arthur James R, Muthukumar K, Rajendran A (2009) Enumeration and identification of pathogenic pollution indicators in the Cauvery river, South India. Res J Microbiol 4:540-549

Langergraber G, Muellegger E (2005) Ecological sanitation - a way to solve global sanitation problems. Environ Int 31:433-444

Lorenzen G, Sprenger C, Taute T, Pekdeger A, Mittal A, Massmann G (2010) Assessment of the potential for bank filtration in a water-stressed megacity (Delhi, India). Environ Earth Sci 61:1419-1434

Madavan N, Subramanian V (2001) Fluoride concentration in river waters of south Asia. Curr Sci 80:1312-1319

Magesh NS, Chandrasekar N (2012) GIS model-based morphometric evaluation of Tamiraparani sub basin, Tirunelveli district, Tamil Nadu, India. Arab J Geosci 7:131-141

Malik RN, Nadeem M (2011) Spatial and temporal characterization of trace elements and nutrients in the Rawal Lake Reservoir, Pakistan using multivariate analysis techniques. Environ Geochem Health 33:525-541

McLellan SL, Salmore AK (2003) Evidence for localized bacterial loading as the cause of chronic beach closings in a freshwater marina. Water Res 37:2700-2708

Moldovana OT, Melega IN, Leveib E, Terentec M (2013) A simple method for assessing biotic indicators and predicting biodiversity in the hyporheic zone of a river polluted with metals. Ecol Indic 24:412-420

Nagvenkar GS, Ramaiah N (2009) Abundance of sewage-pollution indicator and human pathogenic bacteria in a tropical estuarine complex. Environ Monit Assess 155:245-256

Niewolak S (1998) Total viable counts and concentration of enteric bacteria in bottom sediments from the czarna hańcza river, northeast Poland. Poli J Environ Stud 7:295-306

Obi CL, Potgieter N, Bessong PO, Matsaung G (2002) Assessment of the microbial quality of river water sources in rural Venda communities in South Africa. Water SA 28:287-292

Paruch AM, Mæhlum T, Robertson L (2014) Changes in Microbial Quality of Irrigation Water Under Different Weather Conditions in Southeast Norway. Environ Process. doi:10.1007/s40710-014-0054-2

Ramaiah N, Kolhe V, Sadhasivan A (2004) Abundance of pollution indicator and pathogenic bacteria in Mumbai waters. Curr Sci 87:435-439

Ramesh R, Purvaja R, Ramesh S, James RA (2002) Historical pollution trends in coastal environments of India. Environ Monit Assess 79:151-176

Ramteke PW, Tewari S (2002) Comparative study of fluorogenic and chromogenic media for specific detection of environmental isolates of thermotolerant Escherichia coli. Environ Monit Assess 79:121-127

Ravichandran S (2003) Hydrological influences on water quality trends in the Tamiraparani basin, South India. Environ Monit Assess 87:293-309

Reed TM, Fryar AE, Brion GM, Ward JW (2011) Differences in pathogen indicators between proximal urban and rural karst springs, Central Kentucky, USA. Environ Earth Sci 64:47-55

Rosso JJ, Schenone NF, Carrera AP, Cirelli AF (2013) Concentration of arsenic in water, sediments and fish species from naturally contaminated rivers. Environ Geochem Health 35:201-214

Scott TM, Rose JB, Jenkins TM, Farrah SR, Lukasik J (2002) Microbial source tracking: current methodology and future directions. Appl Environ Microbiol 68:5796-5803 
Solai A, Suresh Gandhi M, Chandrasekaran K, Ram Mohan V (2013) Depositional environment in and around Tamiraparani estuary, and off Tuticorin, Tamil Nadu, India: clues from grain size studies. Arab J Geosci 6: 2419-2446

Sood A, Singh KD, Pandey P, Sharma S (2008) Assessment of bacterial indicators and physicochemical parameters to investigate pollution status of the Gangetic river system of Uttarakhand (India). Ecol Indic 99:709-717

Vagnetti R, Miana P, Fabris M, Pavoni B (2003) Self-purification ability of a resurgence stream. Chemosphere 52:121-130

Vignesh S, Muthukumar K, Arthur James R (2012) Antibiotic resistant pathogens versus human impacts: a study from three eco-regions of the Chennai coast, southern India. Mar Pollut Bull 64:790-800

Vignesh S, Muthukumar K, Gokul MS, James RA (2013) Microbial Pollution Indicators in the Cauvery River, Southern India. Mu Ramkumar (ed.) On a Sustainable Future of the Earth's Natural Resources, Springer Earth System Scinces, 363-376

Vignesh S, Dahms HU, Emmanuel KV, Gokul MS, Muthukumar K, Kim BR, James RA (2014) Physicochemical parameters aid microbial community? A case study from marine recreational beaches, Southern India. Environ Monit Assess 186(3):1875-1887

Wampler PJ, Sisson AJ (2011) Spring flow, bacterial contamination, and water resources in rural Haiti. Environ Earth Sci 62:1619-1628

WHO -The World health statistics 2012 report. 16th May 2012, Geneva, [http:/www.who.int/mediacentre/news/ releases/2012/world health_statistics 20120516/en/i ndex.htmL]

Wilkinson J, Jenkins A, Wyer M, Kay D (1995) Modelling faecal coliform dynamics in streams and rivers. Water Res 29:847-855

Wilson JP, Mitasova H, Wright DJ (2000) Water resource applications of geographic information system. J Urban Reg Inform Syst Assoc 12:6-79

Wotton RS (2004) The essential role of exopolymers (EPS) in aquatic systems. Oceanogr J Mar Biol Annu Rev 42:57-94

Yillia PT, Kreuzinger N, Mathooko JM (2008a) The effect of in-stream activities on the Njoro River - Part I: Stream flow and chemical water quality. Phys Chem Earth 3:722-728

Yillia PT, Kreuzinger N, Mathooko JM (2008b) The effect of in-stream activities on the Njoro river, Kenya. Part II: microbial water quality. Phys Chem Earth 33:729-737 